\title{
IMPLEMENTASI METODE SIMPLE ADDITIVE WEIGHTING (SAW) DALAM SISTEM PENDUKUNG KEPUTUSAN PENENTUAN PENERIMA BANTUAN KORBAN BENCANA ALAM GEMPA (STUDI KASUS: BPBD LOMBOK BARAT)
}

\author{
(Implementation of Simple Additive Weighting (SAW) Method in The Decision \\ Support System for Determination of Beneficiary from Earthquake Victim (Case \\ Study: West Lombok BPBD))
}

\author{
Ahmad Maulana Ari Septian*, Royana Afwani, Moh. Ali Albar \\ Program Studi Teknik Informatika, Fakultas Teknik, Universitas Mataram \\ JI. Majapahit 62, Mataram, Lombok NTB, INDONESIA \\ Email: ahmadseptian96@gmail.com, [royana, mohalialbar] @unram.ac.id
}

\begin{abstract}
Earthquake is one of the natural disasters that result in material and non-material losses for the affected regions and communities. The government through a government agency namely the Regional Disaster Management Agency (BPBD) conducts assistance activities for affected victims based on several criteria of damage to houses suffered, consist of minor, moderate, and severe damage. In determining the criteria, we needed the victim's house data, however current data collection is still done manually, which is to fill in the form of damage to the house suffered by the victim so that it takes a lot of time to do the data collection and determination of the criteria. therefore, a website-based Decision Support System (DSS) will be built using a Codeigniter framework with the PHP programming language and MYSQL database. In this system, the calculation uses the Simple Additive Weighting (SAW) method, because this method is quite in accordance with the topic of the problem in the research conducted. The final result of the development of this system is in the form of a decision on the category of damage to the houses of victims of an earthquake with minor damage, moderate damage or severe damage.
\end{abstract}

Keywords: Decision Support System, Simple Additive Weighting, SAW, Information System, Website.

*Penulis Korespondensi

\section{Pendahuluan}

Indonesia adalah salah satu negara yang terletak antara pertemuan sirkum mediterania dan rangkaian sirkum pasifik dengan proses pembentukan gunung berapi yang masih berlangsung. Oleh sebab itu hampir setiap tahun, Indonesia dilanda bencana alam salah satunya bencana alam gempa bumi baik dengan disertai tsunami maupun tidak[1]. Dalam catatan bencana gempa besar yang pernah terjadi di Indonesia diantaranya ialah gempa besar yang pernah terjadi pada bulan Agustus tahun 2018 lalu di Pulau Lombok dengan kekuatan magnitudo 7.0 skala richter yang menyebabkan kerusakan rumah warga untuk wilayah Lombok Barat sejumlah 13.026 rumah rusak berat, 12.188 rumah rusak sedang dan 44.554 rumah rusak ringan[2].

Badan Nasional Penanggulangan Bencana (BNPB) dan Badan Penanggulangan Bencana Daerah (BPBD) ialah lembaga negara dalam mengurusi bencana alam yang terjadi baik dalam skala nasional dan skala daerah. Badan Nasional ini akan selalu terkait dalam melakukan kegiatan rehabilitasi dan rekontruksi pasca bencana gempa. Salah satu bentuk kegiatannya adalah pemberian bantuan bagi para korban terdampak bencana alam gempa. Untuk metode penyaluran bantuan saat ini ialah sesuai dengan Instruksi Presiden (Inpres) No 5 tahun 2018 mengenai penyaluran bantunan keuangan terhadap korban bencana alam gempa, dalam instruksi tersebut faktor penentunya berdasarkan pada tingkat kerusakan bangunan rumah korban. Ada beberapa variabel yang digunakan sebagai tolak ukur untuk tingkat kerusakan bangunan yang terjadi diantaranya ialah pondasi bangunan, kolom/ring balok bangunan, rangka atap (kuda-kuda) bangunan, penutup atap/genteng, langitlangit/platfon, dinding, dan lantai yang setiap variabel tersebut memiliki bobot tersendiri untuk dihitung dalam menentukan keputusan tingkat kerusakan yang dialami. 
Sesuai dengan hasil wawancara ke pihak BPBD mengenai sistem penilaian tingkat kerusakan dari bangunan rumah korban, datanya masih belum sepenuhnya terdigitalisasi yang dalam penyimpanan datanya masih berupa tumpukan kertas dan untuk pengumpulan data korban beserta kerusakan rumah atau gedung yang dialami masih dilakukan secara manual oleh team survey yang turun langsung ke lokasi bencana dan dibantu oleh aparat dari desa setempat. Sementara dalam menentukan penerima bantuan korban bencana alam gempa diperlukan keputusan yang tepat dan cepat sehingga dapat memenuhi kebutuhan korban terdampak gempa dalam memulihkan kehidupan sosial mereka pasca gempa terjadi.

Berdasarkan pemaparan dan permasalahan tersebut dalam penelitian ini akan dikembangkan sebuah sistem pendukung keputusan untuk penentuan penerima bantuan korban bencana alam gempa berbasis website yang bisa digunakan dalam pendataan para korban terdampak bencana gempa dan untuk metode pendukung keputusanya menggunakan metode Simple Additive Weighting (SAW) sebagai metode alternatif penentuan penerima bantuan korban bencana alam gempa.

\section{TINJAUAN PUSTAKA DAN DASAR TEORI}

\subsection{Tinjauan Pustaka}

Penelitian dengan menggunakan metode Simple Additive Weighting (SAW) sebagai metode dalam sistem pendukung keputusan telah dilakukan oleh beberapa peneiliti dalam beberapa kasus diantaranya sebagai berikut

Pada Penelitian yang dilakukan oleh M. Yusup pada penelitiannya menentukan layak atau tidaknya kredit yang akan diberikan pada calon nasabah dengan melihat beberapa kriteria penilaian. Variabel yang digunakan untuk diperhitungkan dalam pengambilan keputusan pada penelitian ini diantaranya pekerjaan nasabah, penghasilan nasabah, jaminan, jumlah tanggungan dan status rumah nasabah. Dalam pengembangan aplikasinya penelitian ini menggunakan aplikasi berbasis website dengan bahasa pemgrogaran PHP murni dan pengolahan datanya menggunakan MySQL. Dan hasil output dari penelitian ini berupa hasil seleksi calon nasabah berupa rekomendasi nama calon nasabah yang diurutkan berdasarkan perangkingan [3].
Selain itu juga dalam penelitian yang dilakukan oleh Oktovantua menyimpulkan bahwa penelitiannya mampu merancang suatu sistem pendukung keputusan menggunakan bahasa pemrograman Visual Basic 6.0 dengan variabel yang digunakan sebagai inputannya ialah pekerjaan dan penghasilan orang tua siswa sehingga output dari penelitian ini ialah rekomendasi nama-nama siswa miskin yang berhak menerima BSM [4].

Dalam penilitian yang dilakukan oleh Baiq Nurul Aini mengenai pengembangan sistem untuk membantu dalam pencarian rumah kos terbaik di sekitar Universitas Mataram dengan variabel yang digunakan untuk perhitungan dalam pengambilan keputusanya ialah jarak, harga, dan fasilitas. Untuk hasil luaran dari penelitiannya ialah berupa rekomendasi kos terbaik disekitar Universitas Mataram [5].

Berdasarkan penelitian yang dilakukan oleh Sabda Gunawan dalam penelitiannya mengembangkan sistem yang dapat membantu dalam pemilihan guru terbaik dengan variabel penilaian yang digunakan ialah kedisiplinan, prestasi, prakarsa, tanggung jawab, dan menjaga nama baik sebagai pendidik. Output atau keluaran dari sistem ini berupa daftar nama-nama guru terbaik berdasarkan perangkingan [6].

Pada penelitian yang dilakukan oleh M. Mustakim yang dalam penelitiannya berhasil mengembangkan suatu sistem pendukung keputusan untuk penentuan penerima bantuan keuangan bencana dengan variabel perhitungan berdasarkan kategori kerusakan, kategori keluarga dan jumlah anggota rumah tangga korban. Kesimpulan hasil luaran dari penilitan ini ialah berupa rekomendasi nama para penerima bantuan bencana [1].

Berdasarkan tinjauan pustaka diatas, maka pada penelitian ini akan dibahas bagaimana cara membangun sistem pendukung keputusan dalam kasus penentuan penerima bantuan korban bencana alam gempa dengan menggunakan metode pendukung keputusan Simple Additive Weighting (SAW) dalam pengambilan keputusanya dan dalam pengambangan sistem yang berbasis website menggunakan bahasa pemrograman PHP dengan framework Codelgniter dan perancangan database menggunakan MySQL. Untuk lebih jelasnya mengenai tinjauan pustaka yang digunakan dapat dilihat pada Gambar 1. 


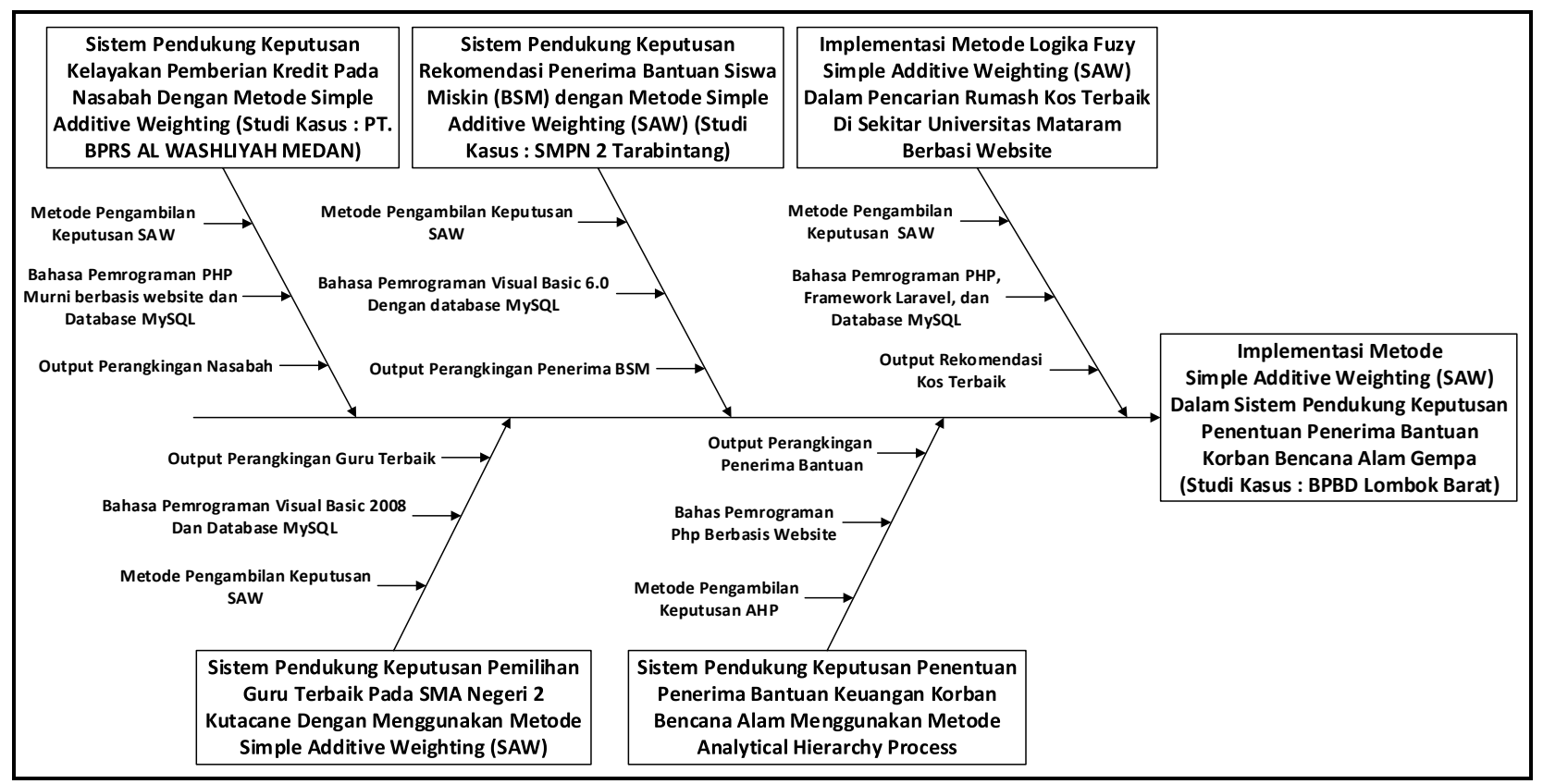

Gambar 1. Fishbone diagram

\subsection{Simple Additive Weighting (SAW)}

Metode SAW ini sering juga dikenal istilah metode penjumlahan terbobot. Konsep dasar metode SAW adalah mencari penjumlahan terbobot dari rating kinerja pada setiap alternatif pada semua atribut. Tahapan dalam metode SAW adalah sebagai berikut [8]:

a. Menentukan kriteria yang dijadikan acuan pengambilan keputusan.

b. Menentukan rating kecocokan setiap alternatif pada setiap kriteria.

c. Membuat matriks keputusan berdasarkan kriteria, kemudian melakukan normalisasi matriks berdasarkan persamaan yang disesuaikan dengan jenis atribut sehingga diperoleh matriks ternormalisasi R.

d. Hasil akhir diperoleh dari proses perangkingan yaitu penjumlahan dari perkalian matriks ternormalisasi $\mathrm{R}$ dengan vector bobot sehingga diperoleh nilai terbesar yang dipilih sebagai alternatif terbaik sebagai solusi.

Formula untuk normalisasi pada metode SAW adalah sebagai berikut:

$$
r_{i j}=\begin{aligned}
& \frac{x_{i j}}{\operatorname{Max} x_{i j}} \text { (jika j adalah atribut benefit) } \\
& \frac{\operatorname{Min} x_{i j}}{x_{i j}} \text { (jika j adalah atribut cost) }
\end{aligned}
$$

Keterangan:

$$
r_{i j} \quad \text { : Rating kinerja ternormalisasi }
$$

Max $_{i j} \quad$ : Nilai maksimum dari setiap baris dan kolom $\operatorname{Min}_{\mathrm{ij}}$ : Nilai minimum dari setiap baris dan kolom $\mathrm{X}_{\mathrm{ij}} \quad$ : Baris dan kolom dalam matriks

$\mathrm{r}_{\mathrm{ij}}$ merupakan rating kinerja ternormalisasi dari alternatif $A_{i}$ pada atribut $C_{j} ; i=1,2, \ldots, m$ dan $j=1,2, \ldots, n$

Nilai preferensi untuk setiap alternatif (Vi) :

$$
v_{i}=\sum_{j=1}^{n} w_{j} r_{i j}
$$

Keterangan:

$\mathrm{V}_{\mathrm{i}} \quad$ : nilai akhir dari alternatif

$\mathrm{w}_{\mathrm{j}} \quad$ : bobot yang telah ditentukan

$r_{i j} \quad$ : normalisasi matriks

Nilai $V_{i}$ yang lebih besar menandakan bahwa alternatif $A_{i}$ lebih tepat untuk dipilih[8].

\section{Metodologi Penelitian}

\subsection{Alat dan Bahan Penelitian}

Alat yang digunakan dalam proses penelitian ini terbagi menjadi dua bagian yaitu perangkat keras dan perangkat lunak, lebih jelasnya dapat dilihat pada Tabel I.

TABEL I. KEBUTUHAN ALAT

\begin{tabular}{|l|l|l|}
\hline No & Jenis Perangkat & Spesifikasi \\
\hline 1 & Perangkat keras & $\begin{array}{l}\text { Laptop ACER Intel }^{\circledR} \\
\text { Core }^{\text {TM }} \text { i3-7130U dengan } \\
\text { RAM 4 GB }\end{array}$ \\
\hline 2 & Perangkat lunak & $\begin{array}{l}\text { Windows 10 Home 64- } \\
\text { bit }\end{array}$ \\
\hline
\end{tabular}




\begin{tabular}{|l|l|l|}
\hline 3 & Perangkat lunak & Text Editor Sublime \\
\hline 4 & Perangkat lunak & $\begin{array}{l}\text { Microsoft office word } \\
2019\end{array}$ \\
\hline 5 & Perangkat lunak & $\begin{array}{l}\text { Microsoft office visio } \\
2019\end{array}$ \\
\hline 6 & Perangkat lunak & Framework Codelgniter \\
\hline 7 & Perangkat lunak & XAMPP \\
\hline
\end{tabular}

Bahan-bahan yang dibutuhkan dalam pengerjaan penelitian ini diantaranya ialah data pribadi dari masyarakat yang menjadi korban terdampak gempa yang diperoleh dari lembaga BPBD dalam bentuk file berformat pdf dan data kerusakan rumah korban berupa file berformat excel beserta panduan tingkat kerusakan aset akibat bencana alam gempa berupa formulir yang diperoleh dari BPBD Lombok Barat.

\subsection{Diagram Alir Penelitian}

Ada beberapa tahapan yang akan dilakukan dalam pengerjaan penelitian ini yang dapat dilihat pada Gambar 2.

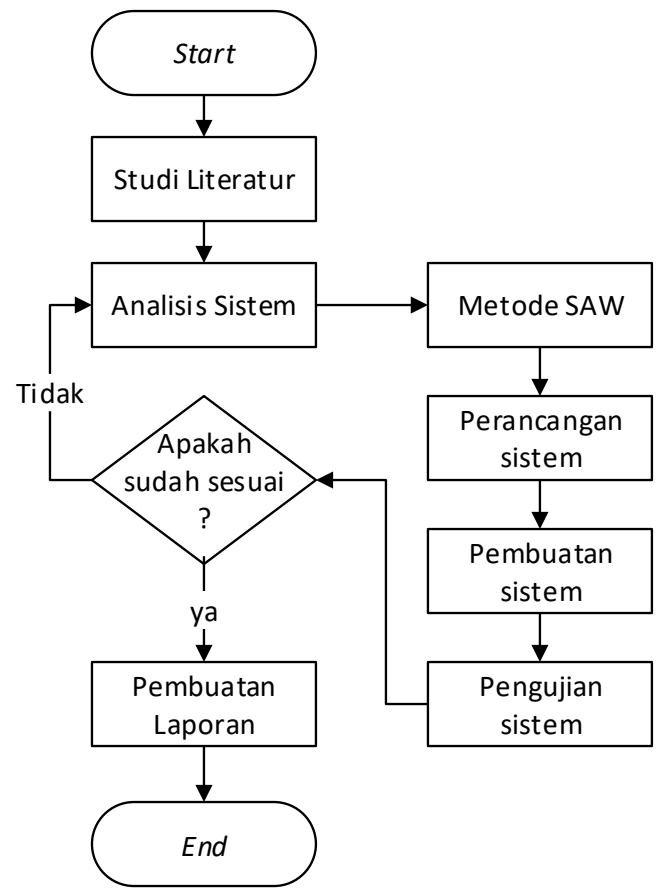

Gambar 2. Diagram alir penelitian

\subsection{Analisis Sistem}

Analisis sistem dibagi menjadi dua yakni analisis sistem yang berjalan dan analisis sistem yang akan dibangun.

\subsubsection{Analisis Sistem Yang Berjalan}

Untuk lebih jelas alur dari sistem yang berjalan di BPBD sebagai berikut: a. BPBD membentuk tim kaji teknis atau team survey yang akan turun ke lokasi bencana gempa untuk melakukan pendataan korban.

b. BPBD dan Team survey mempersiapkan berkasberkas berupa form isian untuk digunakan dalam melakukan pendataan korban.

c. Team survey turun ke lokasi bencana untuk melakukan pendataan dengan mengisi berkas form isian sesuai dengan yang terjadi dilapangan.

d. Team survey membawa data-data para korban berupa berkas-berkas form isian ke BPBD untuk diolah kembali.

e. BPBD mengolah data korban yang sudah terkumpul guna memberikan rekomendasi untuk bisa dikeluarkan surat keterangan rusak ringan, rusak sedang, dan rusak berat dengan membentuk tim survei.

Lebih jelasnya mengenai analisis sistem yang berjalan dapat dilihat pada Gambar 3.

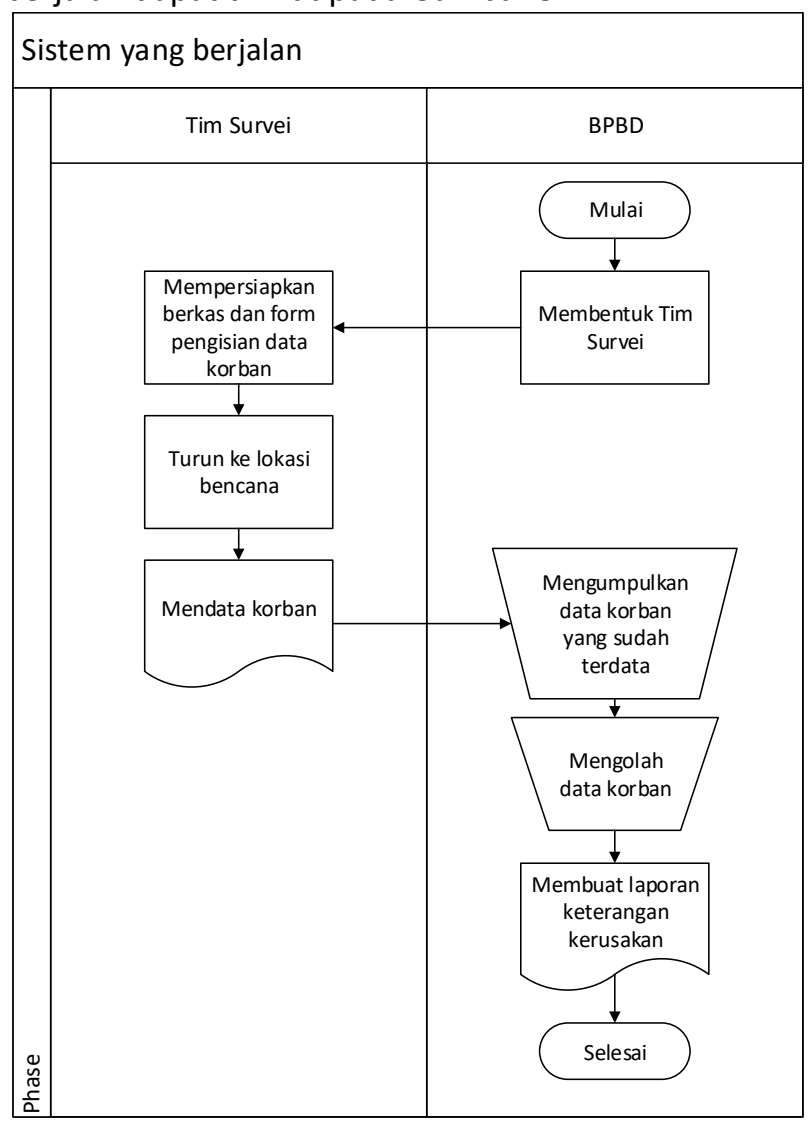

Gambar 3. Sistem yang berjalan

\subsubsection{Analisis Sistem Yang Akan Dibangun}

Untuk alur kerja dari sistem yang akan dibangun ini ialah sebagai berikut:

a. BPBD membentuk tim kaji teknis atau team survey, kemudian melakukan persiapan turun 
ke lokasi bencana untuk melakukan pendataan korban bencana.

b. BPBD dan Team survey mempersiapkan sistem untuk digunakan dalam melakukan pendataan korban dan diberikan akun masing-masing untuk bisa melakukan login kedalam sistem sebagai user admin, user team survey dan user Kabag.

c. Team survey turun ke lokasi bencana untuk melakukan pendataan dengan mengakses website dan melakukan login sebelum bisa mengisi halaman form input data.

d. Team survey melakukan input data korban pada halaman form input data korban sesuai dengan yang terjadi kemudian men-submit data ke dalam sistem.

e. Setelah menekan tombol submit data langsung diolah dengan metode pendukung keputusan SAW.

f. Data yang sudah diolah menggunakan metode SAW akan memberikan hasil keputusan yang langsung terkirim dan tersimpan ke database.

Lebih jelasnya mengenai analisis sistem yang akan dibangun dapat dilihat pada Gambar 4.

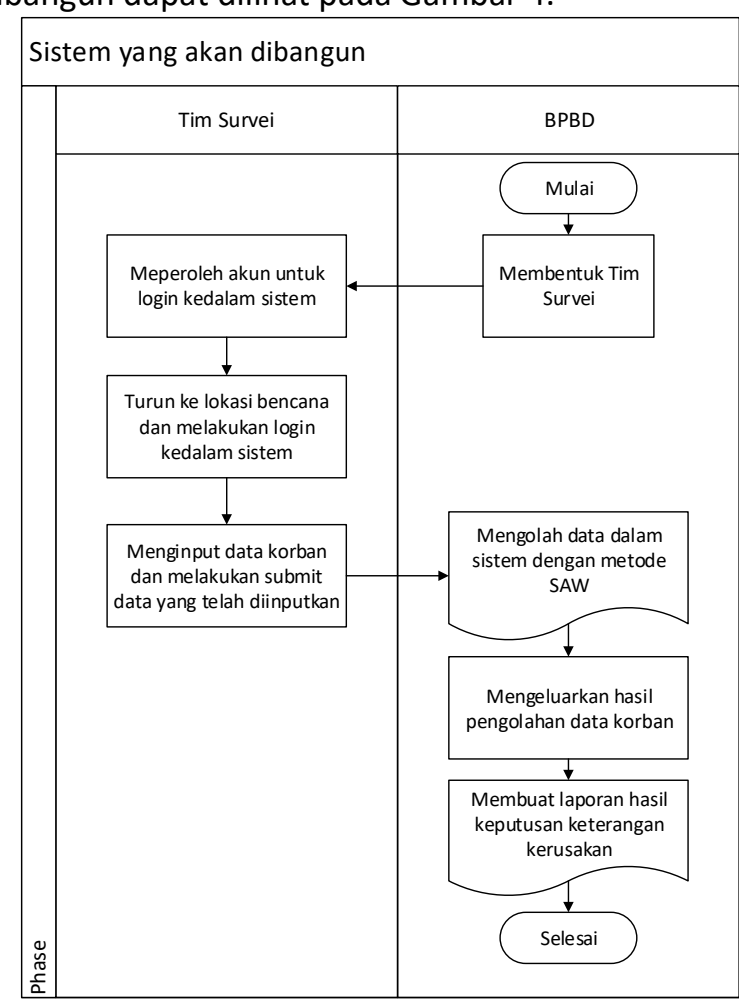

Gambar 4. Sistem yang akan dibangun

\subsection{Metode Simple Additive Weighting (SAW)}

Berikut langkah-langkah yang dilakukan dalam perhitungan untuk mendapatkan hasil keputusan yang terbaik menggunakan metode SAW:
Langkah pertama ialah pemberian bobot awal untuk setiap kriteria ( $\mathrm{Ci}$ ) dapat dilihat pada TABEL II.

Untuk perhitungan nilai perbaikan bobot yang ditentukan (Wj) berdasarkan pada ketentuan nilai bobot yang telah ditetapkan (Ci) dari setiap kriteria dilakukan perhitungan sebagai berikut.

$$
\mathrm{W}_{1}=\frac{C 1}{\sum C i}=\frac{5}{275}=0.0182
$$

Seterusnnya dilakukan perhitungan (3) untuk setiap masing-masing bobotnya sehingga diperoleh nilai bobot perbaikan yang dapat dilihat pada Tabel II.

TABEL II. BOBOT AWAL DAN PERBAIKAN

\begin{tabular}{|c|c|c|}
\hline Kriteria & Bobot Awal (Ci) & Bobot Perbaikan (Wj) \\
\hline C1 & 5 & 0.0182 \\
\hline C2 & 5 & 0.0182 \\
\hline C3 & 11 & 0.04 \\
\hline C4 & 15 & 0.0545 \\
\hline C5 & 15 & 0.0545 \\
\hline C6 & 11 & 0.04 \\
\hline C7 & 11 & 0.04 \\
\hline C8 & 25 & 0.0909 \\
\hline C9 & 35 & 0.1273 \\
\hline C10 & 35 & 0.1273 \\
\hline C11 & 5 & 0.0182 \\
\hline C12 & 11 & 0.04 \\
\hline C13 & 15 & 0.0545 \\
\hline C14 & 5 & 0.0182 \\
\hline C15 & 2 & 0.0073 \\
\hline C16 & 5 & 0.0182 \\
\hline C17 & 5 & 0.0182 \\
\hline C18 & 5 & 0.0182 \\
\hline C19 & 11 & 0.04 \\
\hline C20 & 15 & 0.0545 \\
\hline C21 & 15 & 0.0545 \\
\hline C22 & 3 & 0.0109 \\
\hline C23 & 10 & 0.0364 \\
\hline Lang & (1) & \\
\hline
\end{tabular}

Langkah kedua ialah menentukan rating kecocokan setiap aternatif dan kriteria dapat dilihat pada Tabel III.

TABEL III. RATING KECOCOKAN ALTERNATIVE DAN KRITERIA

\begin{tabular}{|c|c|c|c|c|}
\hline \multirow{2}{*}{ Kriteria } & \multicolumn{4}{|c|}{ Alternatif } \\
\cline { 2 - 5 } & $\mathrm{A} 1$ & $\mathrm{~A} 2$ & $\mathrm{~A} 3$ & $\mathrm{~A} 4$ \\
\hline C1 & 4 & 0 & 0 & 4 \\
\hline C2 & 3 & 3 & 5 & 5 \\
\hline C3 & 0 & 8 & 8 & 5 \\
\hline C4 & 0 & 11 & 0 & 0 \\
\hline C5 & 0 & 0 & 11 & 0 \\
\hline C6 & 0 & 11 & 11 & 0 \\
\hline
\end{tabular}




\begin{tabular}{|c|c|c|c|c|}
\hline C7 & 7 & 0 & 0 & 11 \\
\hline C8 & 0 & 0 & 12 & 19 \\
\hline C9 & 0 & 0 & 26 & 0 \\
\hline C10 & 0 & 26 & 0 & 0 \\
\hline C11 & 0 & 4 & 3 & 5 \\
\hline C12 & 5 & 5 & 0 & 11 \\
\hline C13 & 0 & 0 & 14 & 0 \\
\hline C14 & 0 & 4 & 5 & 5 \\
\hline C15 & 1 & 2 & 0 & 0 \\
\hline C16 & 0 & 0 & 4 & 4 \\
\hline C17 & 4 & 0 & 5 & 0 \\
\hline C18 & 4 & 5 & 3 & 5 \\
\hline C19 & 0 & 0 & 0 & 8 \\
\hline C20 & 0 & 0 & 11 & 0 \\
\hline C21 & 0 & 0 & 11 & 0 \\
\hline C22 & 3 & 3 & 0 & 0 \\
\hline C23 & 0 & 8 & 10 & 9 \\
\hline
\end{tabular}

Langkah ketiga ialah pembentukan matriks $X$ dan matriks normalisasi $\left(R_{i j}\right)$ dapat dilihat pada Gambar 5 .

$\mathrm{X}=\left\{\begin{array}{ccccccccccccccccccccccc}4 & 3 & 0 & 0 & 0 & 0 & 7 & 0 & 0 & 0 & 0 & 5 & 0 & 0 & 1 & 0 & 4 & 4 & 0 & 0 & 0 & 3 & 0 \\ 0 & 3 & 8 & 11 & 0 & 11 & 0 & 0 & 0 & 26 & 4 & 5 & 0 & 4 & 2 & 0 & 0 & 5 & 0 & 0 & 0 & 3 & 8 \\ 0 & 5 & 8 & 0 & 11 & 11 & 0 & 12 & 26 & 0 & 3 & 0 & 14 & 5 & 0 & 4 & 5 & 3 & 0 & 11 & 11 & 0 & 10 \\ 4 & 5 & 5 & 0 & 0 & 0 & 11 & 19 & 0 & 0 & 5 & 11 & 0 & 5 & 0 & 4 & 0 & 5 & 8 & 0 & 0 & 0 & 9\end{array}\right\}$

\section{Gambar 5. Matriks X}

Dari matriks keputusan $\mathrm{X}$ dilakukan normalisasi menjadi matriks ternormalisasi (Rij) dengan perhitungan sebagai berikut.

$$
R_{11}=\frac{x_{11}}{\operatorname{Max} x_{11}}=\frac{4}{\operatorname{Max}\left\{\begin{array}{lll}
4 & 0 & 0
\end{array}\right\}}=1
$$

Perhitungan (4) terus dilakukan untuk setiap index sehingga diperoleh matriks Rij dapat dilihat pada Gambar 6,

$\left(\begin{array}{lllllllllllllllllllllll}1 & 0.6 & 0 & 0 & 0 & 0 & 0.6364 & 0 & 0 & 0 & 0 & 0.4545 & 0 & 0 & 0.5 & 0 & 0.8 & 0.8 & 0 & 0 & 0 & 1 & 0\end{array}\right.$ $R_{i j}=\left(\begin{array}{llllllllllllllllllllllll}0 & 0.6 & 1 & 1 & 0 & 1 & 0 & 0 & 0 & 1 & 0.8 & 0.4545 & 0 & 0.8 & 1 & 0 & 0 & 1 & 0 & 0 & 0 & 1 & 0.8\end{array}\right.$

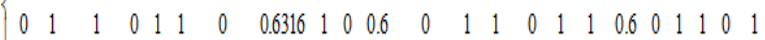

$\begin{array}{lllllllllllllllllllllll}1 & 1 & 0.625 & 0 & 0 & 0 & 1 & 1 & 0 & 0 & 1 & 1 & 0 & 1 & 0 & 1 & 0 & 1 & 1 & 0 & 0 & 0 & 0.9\end{array}$

Gambar 6. Matriks $\mathrm{R}_{\mathrm{ij}}$

Langkah keempat ialah proses perangkingan dilakukan dengan langkah berikut:

$\mathrm{Vi}=(\mathrm{Rij}) *(\mathrm{Wi})$

$\mathrm{V} 1=(1) *(0.0182)+\ldots+(0) *(0.0364)=0.1226$

Seterusnya dilakukan perhitungan yang sama menggunakan persamaan (4) untuk Vi selanjutnya sehingga diperoleh hasil perangkingan yang akan dibandingkan dengan kriteria kerusakan sebagai berikut:
TABEL IV. TINGKAT KERUSAKAN

\begin{tabular}{|c|c|}
\hline Klasifikasi Kerusakan & $\begin{array}{c}\text { Persentase Tingkat } \\
\text { Kerusakan }\end{array}$ \\
\hline Rusak Ringan & $\leq 30 \%$ \\
\hline Rusak Sedang & $31-70 \%$ \\
\hline Rusak Berat & $\geq 71 \%$ \\
\hline
\end{tabular}

TABEL V. HASIL PERANGKINGAN

\begin{tabular}{|c|c|c|c|}
\hline Alternatif & Nilai & Persentase & $\begin{array}{c}\text { Kategori } \\
\text { Kerusakan }\end{array}$ \\
\hline A1 & 0.1164 & $11.64 \%$ & Rusak ringan \\
\hline A2 & 0.3855 & $38.55 \%$ & Rusak sedang \\
\hline A3 & 0.6137 & $61.37 \%$ & Rusak sedang \\
\hline A4 & 0.3778 & $37.78 \%$ & Rusak sedang \\
\hline
\end{tabular}

\subsection{Perancangan Sistem}

Berikut perancangan atau desain dari sistem yang akan dibangun.

\subsubsection{Use case diagram}

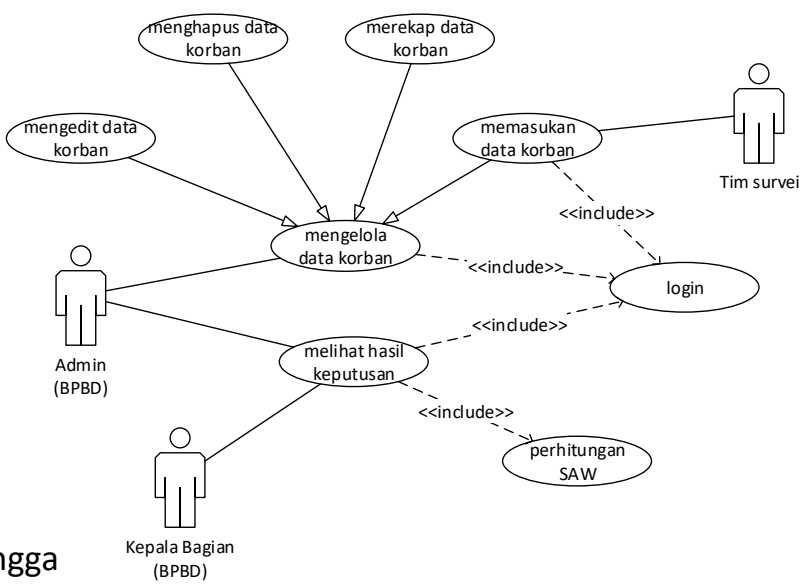

Gambar 7. Use case diagram

Dari Gambar 7 dapat diketahui bahwa terdapat tiga user yang akan menggunakan sistem yakni user admin, user team survey dan user Kabag, hal-hal yang dapat dilakukan oleh masing-masing user.

\subsubsection{Class Diagram}

Dalam perancangan sistem ini menggunakan pola arsitektur Model View Controller (MVC). Sehingga dilakukan perancangan kelas-kelas yang ada pada sistem yang terdiri dari kelas Model, View, dan Controller yang berelasi satu sama lain dapat dilihat pada Gambar 8. 


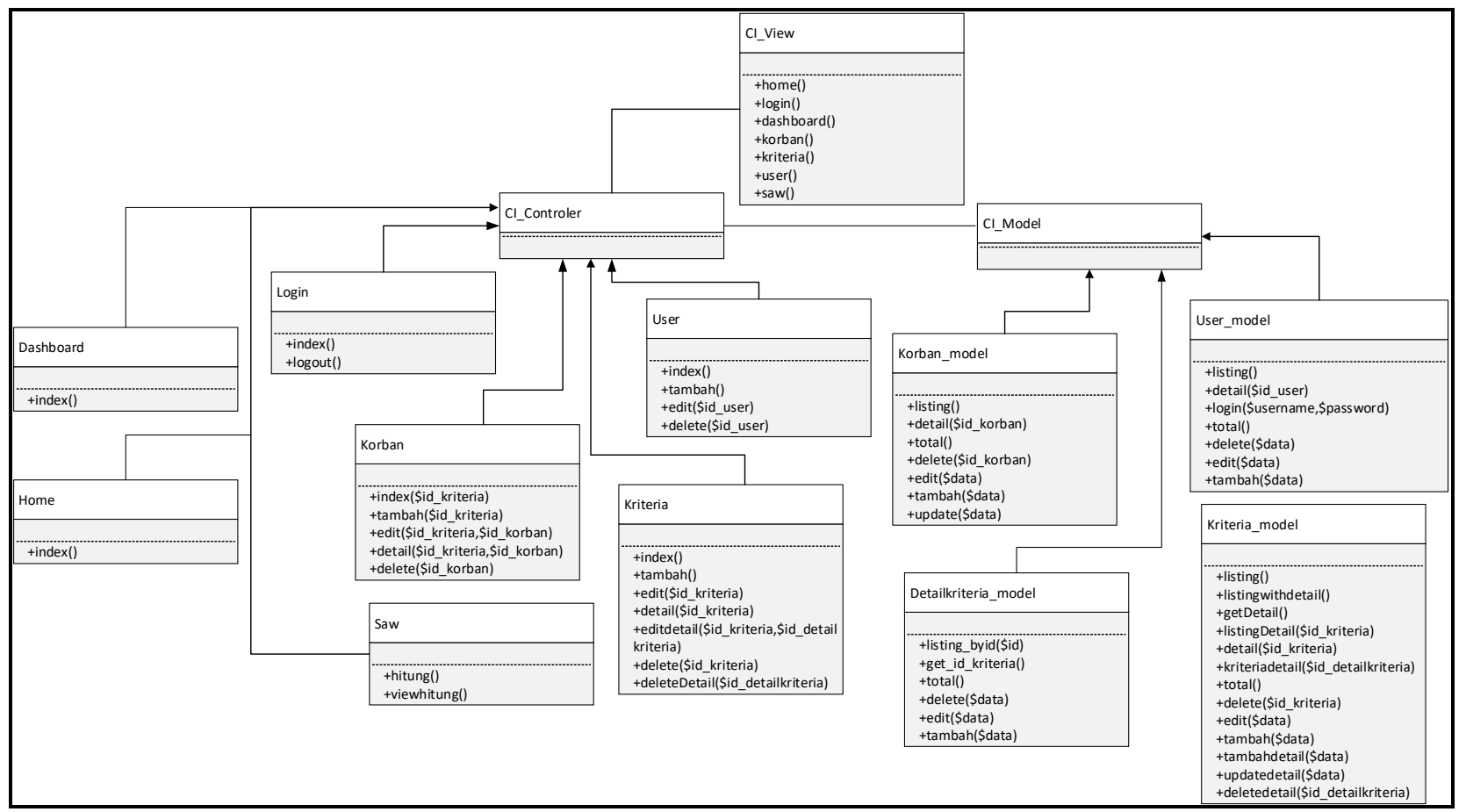

Gambar 8. Class diagram

Dari Gambar 8 dapat dilihat terdapat beberapa kelas yang dirancang terdiri dari kelas view, controller dan model, untuk kelas controller ada 7 kelas diantaranya Login, Korban, Kriteria, User, Saw,

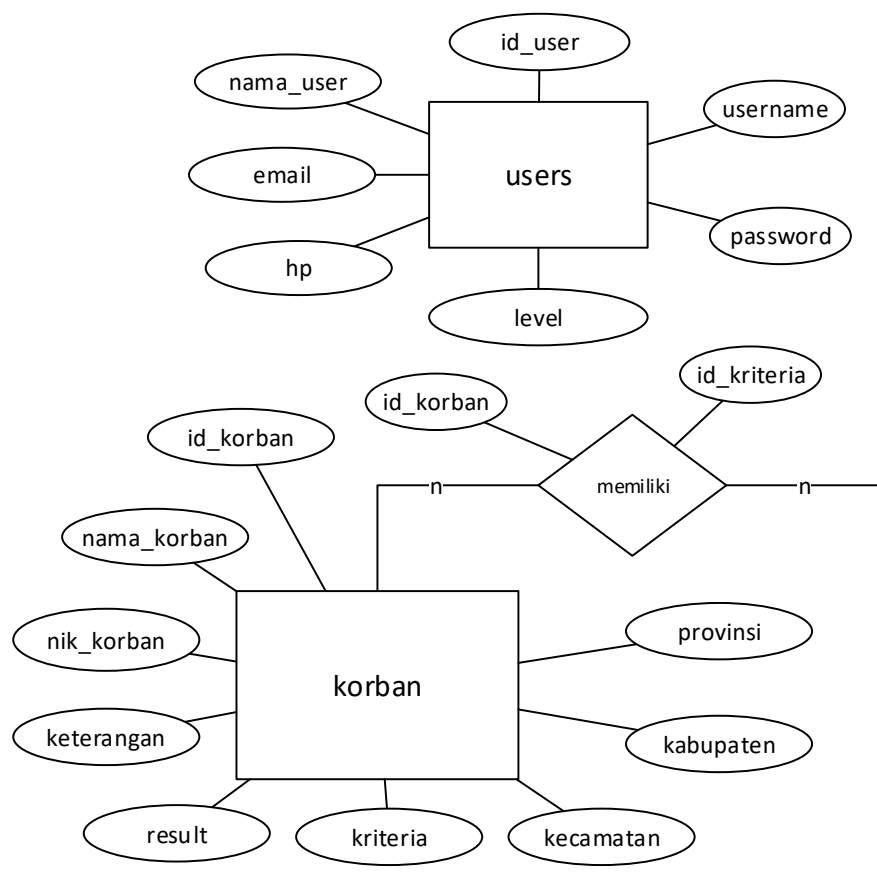

Gambar 9. Entity relationiship diagram (ERD)

\subsubsection{Entity relationship diagram (ERD)}

Entity Relation Diagram (ERD) merupakan sebuah diagram yang digunakan untuk merancang hubungan
Dashboard dan Home. Untuk kelas model ada 4 diantaranya Korban_model, Kriteria_model, Detailkriteria_model dan User_model.

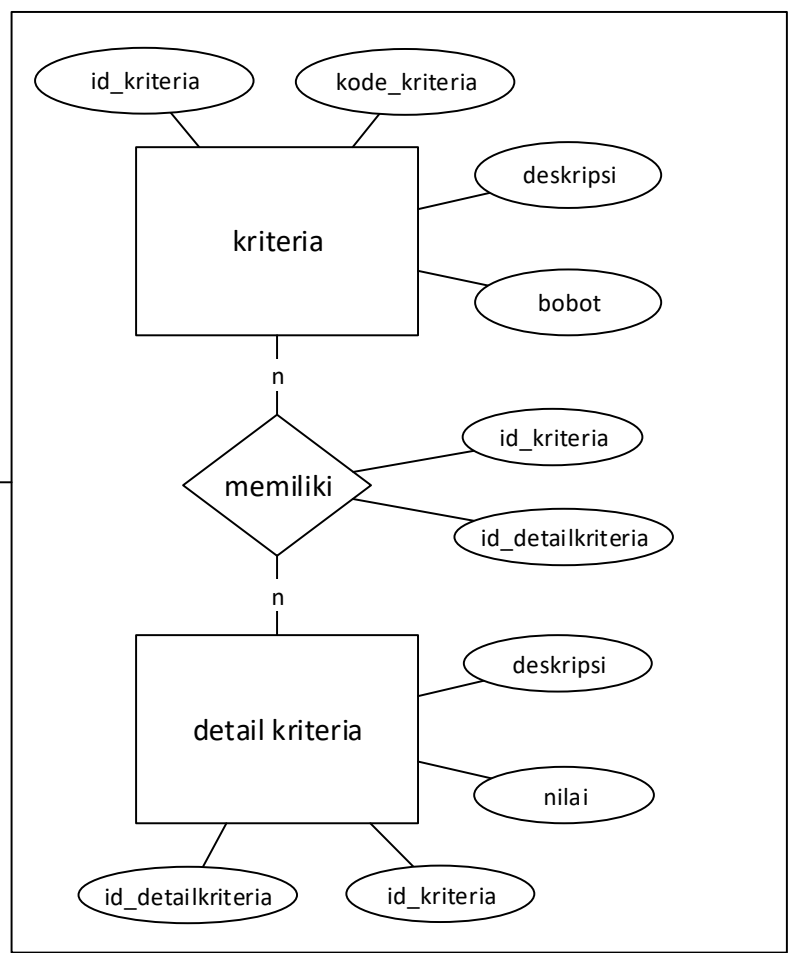

antar tabel-tabel data dalam sistem. Didalam sistem penentuan penerima korban bencana alam gempa ini dirancang ERD yang terdiri dari empat entitas yaitu 
Users, korban, kriteria dan detailkriteria. Untuk lebih jelasnya mengenai keterkaitan antar entitas dapat dilihat pada Gambar 9.

\section{Hasil dan Pembahasan}

\subsection{Implementasi Sistem}

Pada tahap ini akan dilakukan implementasi dari hasil perancangan sistem pada sub bab sebelumnya, beberapa implementasi yang dilakukan sebagai berikut:

\subsubsection{Implementasi database}

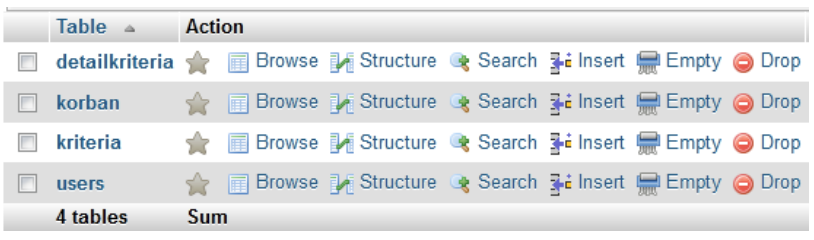

Gambar 10. Implementasi database

Gambar 10 merupakan implementasi database yang diberi nama database db_gempa, terdapat 4 (empat) tabel terdiri dari tabel detailkriteria, tabel korban, tabel kriteria dan tabel users.

\subsubsection{Implementasi class}

Selanjutnya akan dibahas implementasi class yang digunakan sesuai dengan struktur class framework Codelgniter yakni dengan struktur MVC (Model View Controller) sebagai berikut:

a. Class Controllers

$\nabla$ controllers
$\square$ Dashboard.php
$\square$ Home.php
$\square$ Korban.php
$\square$ Kriteria.php
$\square$ Laporan.php
$\square$ Login.php
$\square$ Saw.php
$\square$ User.php

Gambar 11. Implementasi class controllers

Gambar 11 merupakan class controllers berfungsi untuk memproses data dalam sistem dan berfungsi menghubungkan antara class models dengan class views.

b. Class Models

$$
\begin{aligned}
& \text { Detailkriteria_model.php } \\
& \text { Korban_model.php } \\
& \text { Kriteria_model.php } \\
& \text { User_model.php }
\end{aligned}
$$

Gambar 12. Implementasi class models
Gambar 12 merupakan class model yang berfungsi mengelola data dalam database, terdapat 4 class models yakni Detailkriteria_model, Korban_model, Kriteria_model dan User_model.

c. Class Views

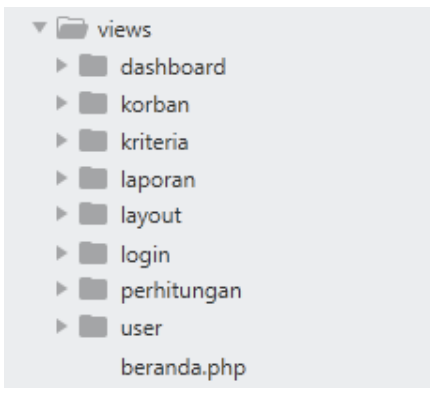

Gambar 13. Implementasi class views

Gambar 13 merupakan class views yang berfungsi mengelola tampilan dari sistem.

\subsubsection{Implementasi Interface}

a. Halaman awal

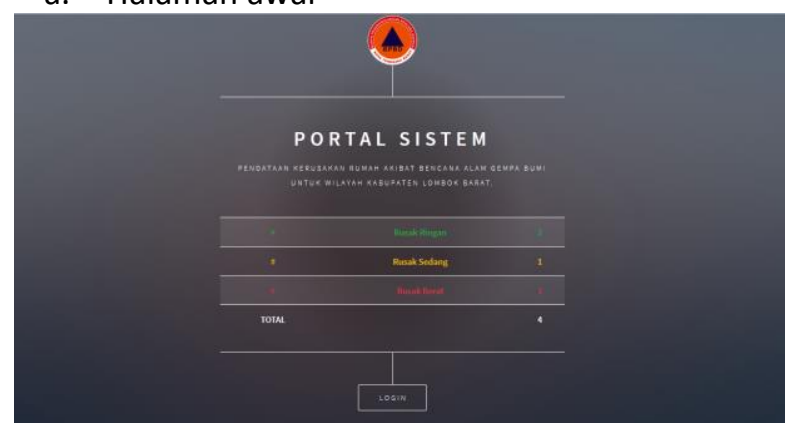

Gambar 14. Halaman awal

Pada Gambar 14 terdapat tampilan awal dari sistem yang berisi deskripsi singkat mengenai sistem, informasi kesimpulan hasil akhir yang diolah oleh sistem. Halaman ini bisa diakses bersama oleh user admin dan user team survey.

b. Halaman login

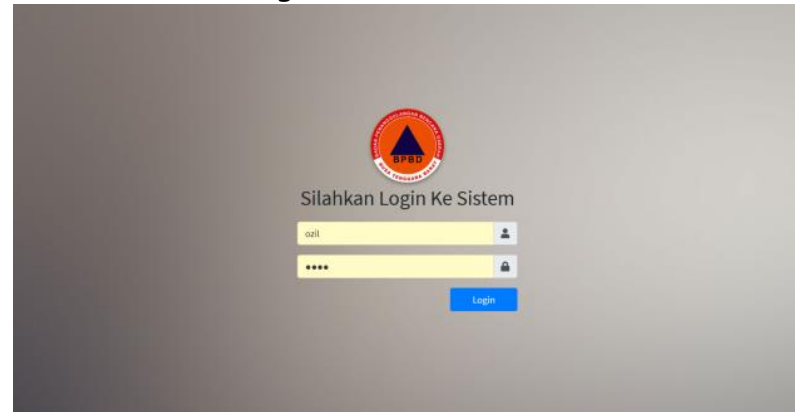

Gambar 15. Halaman login

Pada Gambar 15 ialah halaman login yang digunakan untuk bisa masuk kedalam sistem dengan 
menggunakan username dan password yang telah diberikan oleh pihak BPBD sebagai admin dari sistem.

\section{c. Halaman dashboard}

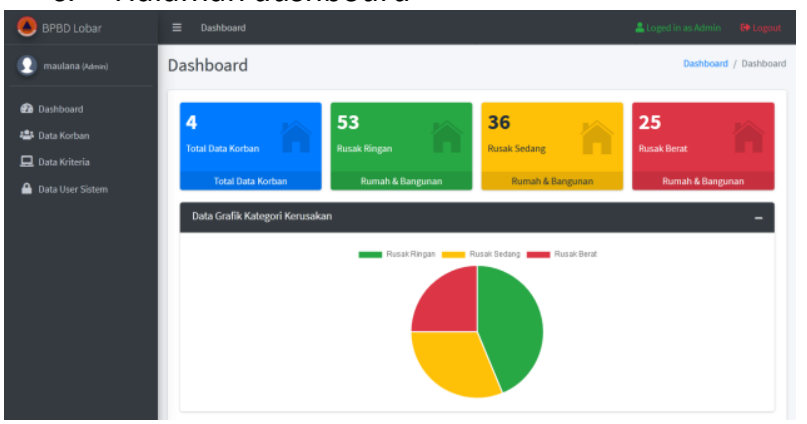

Gambar 16. Halaman dashboard

Pada Gambar 16 terdapat widget data diantaranya total keseluruhan data korban, total data rusak ringan, total data rusak sedang dan total data rusak berat, beserta data grafik untuk memudahkan melihat perbandingan dari masing-masing data. Halaman ini hanya bisa diakses oleh user admin.

d. Halaman data korban

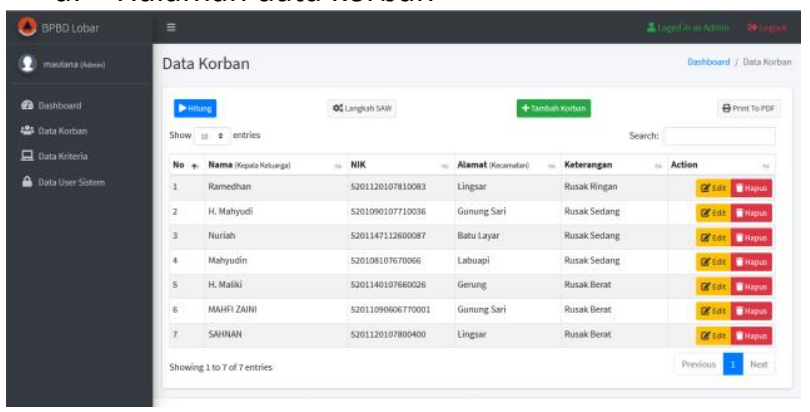

Gambar 17. Halaman data korban

Pada Gambar 17 terdapat tabel yang berisi data para korban beserta aksi yang bisa dilakukan yakni mengedit dan menghapus data, halaman ini hanya bisa diakses oleh user admin.

e. Halaman perhitungan SAW

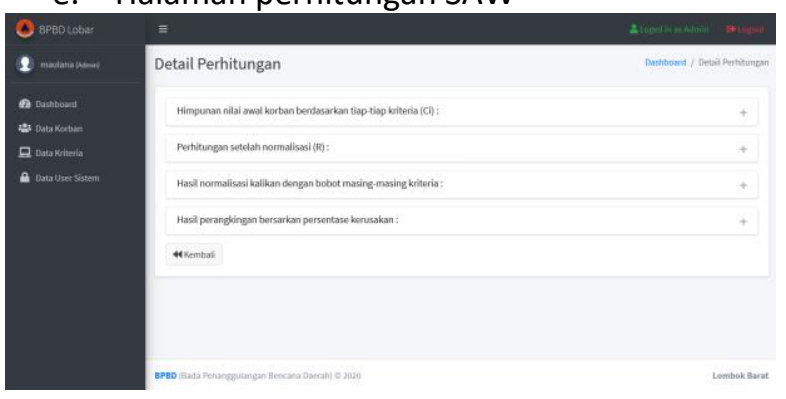

Gambar 18. Halaman perhitungan SAW

Pada Gambar 18 terdapat pemaparan langkahlangkah perhitungan data yang dilakukan oleh sistem sesuai dengan metode yang di implementasikan yakni metode simple additive weighting (SAW).

\subsection{Hasil pengujian}

Untuk hasil pengujian sistem dilakukan dengan 3 metode pengujian sebagai berikut:

\subsubsection{Pengujian white box}

Pengujian white box pada sistem ini akan dilakukan pada bagian algoritma Simple Additive Weighting (SAW) dengan hasil pengujian dapat dilihat pada Tabel VI.

TABEL VI. HASIL PENGUJIAN WHITE BOX

\begin{tabular}{|c|c|c|c|}
\hline Path & Kasus Uji & Hasil uji & Ket. \\
\hline 1 & $\begin{array}{c}\text { Menginputkan } \\
\text { setiap nilai dari } \\
\text { kriteria } \\
\text { kerusakan }\end{array}$ & $\begin{array}{c}\text { Hasil } \\
\text { perangkingan } \\
\text { ditemukan }\end{array}$ & $\begin{array}{c}{[\boldsymbol{V}] \text { Alur }} \\
\text { terlewati }\end{array}$ \\
\hline 2 & $\begin{array}{c}\text { Variabel \$result } \\
\text { tidak berisi }\end{array}$ & $\begin{array}{c}\text { Variabel } \\
\text { \$result } \\
\text { kosong }\end{array}$ & $\begin{array}{c}{[\boldsymbol{V}] \text { Alur }} \\
\text { terlewati }\end{array}$ \\
\hline
\end{tabular}

\subsubsection{Pengujian black box}

Pengujian dengan menggunakan metode black box dilakukan pada setiap fungsi dari fitur-fitur yang terdapat dalam sistem yang terbagi menjadi dua yakni fitur-fitur sebagai user admin dan sebagai user team survey yang dijabarkan pada Tabel VII.

TABEL VII. HASIL PENGUIIAN BLACK BOX FITUR $A D M I N$

\begin{tabular}{|c|c|c|c|}
\hline \multirow[t]{2}{*}{ No } & \multirow[t]{2}{*}{ Fungsi } & \multicolumn{2}{|c|}{$\begin{array}{c}\text { Hasil } \\
\text { Pengujian }\end{array}$} \\
\hline & & Sesuai & Tidak \\
\hline 1 & Login sebagai admin & $\checkmark$ & \\
\hline 2 & $\begin{array}{l}\text { Menampilkan halaman } \\
\text { dashboard }\end{array}$ & $\sqrt{ }$ & \\
\hline 3 & Menampilkan data korban & $\sqrt{ }$ & \\
\hline 4 & $\begin{array}{l}\text { Melakukan perhitungan } \\
\text { data }\end{array}$ & $\checkmark$ & \\
\hline 5 & Menambahkan data korban & $\sqrt{ }$ & \\
\hline 6 & Mengubah data korban & $\checkmark$ & \\
\hline 7 & Menghapus data korban & $\sqrt{ }$ & \\
\hline 8 & Menampilkan data kriteria & $\sqrt{ }$ & \\
\hline 9 & Menambah data kriteria & $\sqrt{ }$ & \\
\hline 10 & Mengubah data kriteria & $\checkmark$ & \\
\hline 11 & Menghapus data kriteria & $\sqrt{ }$ & \\
\hline 12 & $\begin{array}{l}\text { Menampilkan detail data } \\
\text { kriteria }\end{array}$ & $\checkmark$ & \\
\hline
\end{tabular}




\begin{tabular}{|c|l|c|c|}
\hline 13 & $\begin{array}{l}\text { Menambah detail data } \\
\text { kriteria }\end{array}$ & $\checkmark$ & \\
\hline 14 & $\begin{array}{l}\text { Mengubah detail data } \\
\text { kriteria }\end{array}$ & $\checkmark$ & \\
\hline 15 & $\begin{array}{l}\text { Menghapus detail data } \\
\text { kriteria }\end{array}$ & $\checkmark$ & \\
\hline 16 & Menampilkan data user & $\checkmark$ & \\
\hline 17 & Menambah data user & $\checkmark$ & \\
\hline 18 & Mengubah data user & $\checkmark$ & \\
\hline 19 & Menghapus data user & $\checkmark$ & \\
\hline 20 & $\begin{array}{l}\text { Menampilkan detail langkah } \\
\text { perhitungan }\end{array}$ & $\checkmark$ & \\
\hline 21 & Menampilkan profile user & $\checkmark$ & \\
\hline 22 & Mencetak laporan & $\checkmark$ & \\
\hline 23 & Logout & $\checkmark$ & \\
\hline
\end{tabular}

TABEL VIII. HASIL PENGUJIAN BLACK BOX TEAM SURVEY

\begin{tabular}{|l|l|l|l|}
\hline \multirow{2}{*}{ No } & \multirow{2}{*}{ Fungsi } & \multicolumn{2}{|c|}{ Hasil Pengujian } \\
\cline { 3 - 4 } & & Sesuai & Tidak \\
\hline 1 & Login sebagai admin & $\checkmark$ & \\
\hline 2 & $\begin{array}{l}\text { Menampilkan halaman } \\
\text { dashboard }\end{array}$ & $\checkmark$ & \\
\hline 3 & Menampilkan data korban & $\checkmark$ & \\
\hline 4 & $\begin{array}{l}\text { Melakukan perhitungan } \\
\text { data }\end{array}$ & $\checkmark$ & \\
\hline
\end{tabular}

\subsubsection{Pengujian user acceptance test (UAT)}

Untuk pengujian dengan menggunakan metode UAT ini dilakukan dengan mencari responden dari pihak terkait yakni user dari lembaga BPBD untuk mencoba menggunakan sistem lalu memberikan penilaian terhadap sistem dalam bentuk kuisioner [10][11]. Untuk pertanyaan-pertanyaan yang diberikan dapat dilihat pada Tabel IX.

tabel iX. PertanyaAn pengujian uat

\begin{tabular}{|l|l|}
\hline No & \multicolumn{1}{|c|}{ Pernyataan } \\
\hline 1 & Apakah tampilan sistem nyaman dilihat ? \\
\hline 2 & Apakah sistem nyaman digunakan ? \\
\hline 3 & $\begin{array}{l}\text { Apakah penggunaan menu atau fitur menu } \\
\text { dalam sistem mudah dimengerti ? }\end{array}$ \\
\hline 4 & $\begin{array}{l}\text { Apakah sistem ini dapat membantu kinerja } \\
\text { user ? }\end{array}$ \\
\hline 5 & $\begin{array}{l}\text { Apakah sistem dapat mempercepat } \\
\text { pekerjaan user ? }\end{array}$ \\
\hline 6 & $\begin{array}{l}\text { Apakah informasi yang disediakan sistem } \\
\text { bermanfaat bagi user ? }\end{array}$ \\
\hline 7 & $\begin{array}{l}\text { Apakah sistem ini sudah sesuai dengan } \\
\text { kebutuhan user ? }\end{array}$ \\
\hline
\end{tabular}

\begin{tabular}{|l|l|}
\hline 8 & $\begin{array}{l}\text { Apakah sistem dapat mempermudah dalam } \\
\text { pengelolaan data korban sesuai yg } \\
\text { dibutuhkan? }\end{array}$ \\
\hline 9 & $\begin{array}{l}\text { Apakah tidak terdapat error saat sistem } \\
\text { dijalankan? }\end{array}$ \\
\hline 10 & $\begin{array}{l}\text { Apakah tidak terdapat menu yang tidak } \\
\text { berjalan saat sistem dijalankan? }\end{array}$ \\
\hline 11 & $\begin{array}{l}\text { Apakah sistem ini bersifat user friendly } \\
\text { (mudah digunakan) ? }\end{array}$ \\
\hline 12 & $\begin{array}{l}\text { Apakah sistem ini menghasilkan laporan data } \\
\text { kerusakan yang dialami korban ? }\end{array}$ \\
\hline 13 & $\begin{array}{l}\text { Apakah laporan yang dihasilkan sudah sesuai } \\
\text { dengan yang diharapkan ? }\end{array}$ \\
\hline
\end{tabular}

Tabel IX merupakan pertanyaan dalam pengujian UAT yang dilakukan, untuk pertanyaan dari nomor 1 sampai dengan 13 merupakan pertanyaan untuk pengujian sistem dari sisi admin, sedangkan untuk nomor 1 sampai dengan nomor 11 merupkana pertanyaan untuk pengujian sistem dari sisi team survey. Untuk hasil dari pengujiannya dapat dilihat pada Tabel $X$.

TABEL X. HASIL PENGUJIAN UAT

\begin{tabular}{|l|l|l|l|}
\hline \multirow{2}{*}{ No } & \multirow{2}{*}{ Pernyataan } & \multicolumn{2}{|c|}{ Sisi Pengujian } \\
\cline { 3 - 4 } & & Admin & Team Survey \\
\hline 1 & Sangat Setuju & 22 & 18 \\
\hline 2 & Setuju & 17 & 15 \\
\hline 3 & Kurang Setuju & 0 & 0 \\
\hline 4 & Tidak Setuju & 0 & 0 \\
\hline 5 & Tidak Tau & 0 & 0 \\
\hline Persentase UAT & $91.2 \%$ & $89 \%$ \\
\hline
\end{tabular}

Berdasarkan hasil pengujian UAT pada Tabel $\mathrm{X}$ dapat dinyatakan bahwa sistem dari sisi admin memperoleh 22 sangat setuju dan 17 setuju dengan grafik pada Gambar 19.

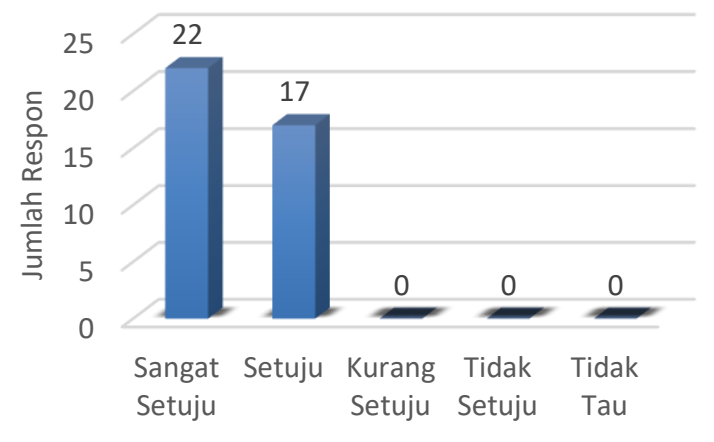

Gambar 19. Diagram pengujian UAT sisi admin 
Sedangkan dari sisi team survey berdasarkan pada Tabel $\mathrm{X}$ memperoleh 18 sangat setuju dan 15 setuju dengan grafik pada Gambar 20.

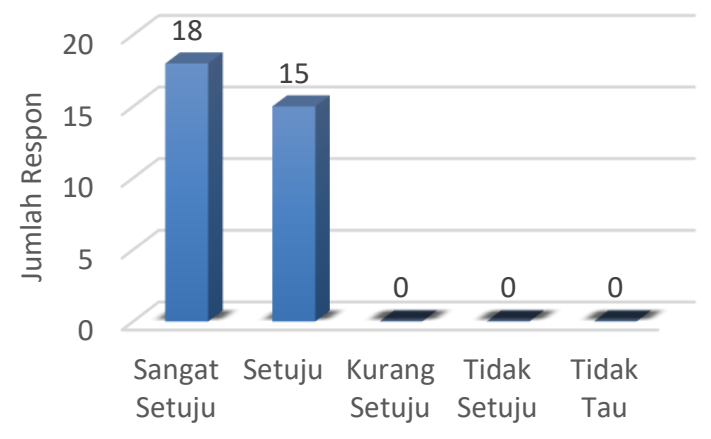

Gambar 20. Diagram pengujian UAT sisi team survey

Dan untuk persentase nilai UAT masing-masing sebesar $91.2 \%$ dan $89 \%$ ini menandakan bahwa sistem sudah baik untuk digunakan walau masih ada beberapa fitur yang perlu ditambahkan untuk dapat digunakan secara maksimal.

\section{Kesimpulan dan SARAN}

\subsection{Kesimpulan}

Setelah dilakukan penelitian dapat diambil beberapa kesimpulan sebagai berikut:

a. Pegawai yang bertindak sebagai user admin maupun team survey dilembaga BPBD dapat melakukan pendataan korban bencana alam gempa secara online menggunakan sistem yang telah dibuat.

b. Dari hasil pengujian white box yang telah dilakukan dapat disimpulkan bahwa algoritma simple additive weighting yang digunakan dalam menentukan kriteria kerusakan rumah korban bencana alam gempa sudah berajalan dan dapat menghasilkan nilai sesuai yang diharapkan.

c. Dari hasil pengujian black box yang telah dilakukan menjelaskan bahwa setiap fungsi dari masing-masing fitur yang ada pada user admin dan user team survey berhasil berjalan sesuai dengan yang direncanakan.

d. Dari hasil pengujian UAT menunjukkan bahwa untuk dari sisi admin diperoleh $91.2 \%$ responden menyatakan sistem sudah sangat baik atau sangat sesuai, kemudian dari sisi team survey diperoleh $89 \%$ responden menyatakan sistem sudah sangat baik atau sesuai.

e. Dari hasil pengujian perbandingan nilai perhitungan SAW manual dengan nilai perhitungan SAW pada sistem didapatkan persentase kesamaan hasil sebesar $100 \%$.

\subsection{Saran}

Setelah dilakukan penelitian, peneliti mengambil beberapa point saran sebagai berikut:

a. Dalam pengembangan kedepannya sistem ini diharapkan bisa digunakan dalam kasus yang berbeda dengan mengganti metode yang digunakan.

b. Untuk fitur dalam sistem ini kedepannya peneliti bisa menambahkan fitur yang dapat memudahkan komunikasi antara team survey dengan admin seperti halnya fitur chat.

c. Dalam penelitian ini masih diperlukan pengembangan lanjutan kedepannya seperti halnya penambahan fitur lapor bagi masyarakat yang belum terdata

\section{DAFTAR PUSTAKA}

[1] M. Mustakim and E. Apriyanto, "Sistem Pendukung Keputusan Penentuan Penerima Bantuan Keuangan Korban Bencana Alam Menggunakan Metode Analytical Hierarchy Process," Semin. Nas. Apl. Teknol. Inf. (SN ATI), pp. 1-6, 2014.

[2] M. H. Pradono, "Kajian Kerentanan Bangunan Pasca Gempa Lombok 5 Agustus 2018," J. Alami J. Teknol. Reduksi Risiko Bencana, vol. 2, no. 2, p. 82, 2018, doi: 10.29122/alami.v2i2.3109.

[3] M. Yusup, "Kredit Pada Nasabah Dengan Metode Simple Additive Weighting ( Studi Kasus Pt . Bprs Al Washliyah Medan )," Pelita Inform. Budi Darma, vol. 9, no. 2, pp. 182-188, 2015.

[4] O. Tp and B. Butar, "Sistem Pendukung Keputusan Rekomendasi Penerima Bantuan Siswa Miskin (BSM) Dengan Metode Simple Additive Weighting (SAW) (Studi Kasus : SMPN2 Tarabintang)," Pelita Inform. Budi Darma, vol. 10, no. April, p. 3, 2015, [Online]. Available: http://www.stmikbudidarma.ac.id//.

[5] B. N. Aini, I. B. K. Widiartha, and R. Afwani, "Implementasi Metode Logika Fuzzy Simple Additive Weighting (SAW) Dalam Pencarian Rumah Kos Terbaik Di Sekitar Universitas Mataram Berbasis Website," J. Comput. Sci. Informatics Eng., vol. 1, no. 1, p. 41, 2018, doi: 10.29303/jcosine.v1i1.71.

[6] S. Gunawan, "Sistem Pendukung Keputusan Pemilihan Guru Terbaik Pada Sma Negeri 2 Kutacane Dengan Menggunakan Metode Simple Additive Weighting (Saw)," Pelita Inform. Budi Darma, vol. 9, no. 3, pp. 143-148, 2015.

[7] Yakub, Pengantar Sistem Informasi. Yoyakarta: Graha Ilmu, 2012.

[8] A. C. Febryanti, I. Darmawan, and R. Andreswari, "Pemodelan Sistem Pendukung Keputusan 
Pemilihan Bidang Peminatan Menggunakan Metode Simple Additive Weighting Studi Kasus : Program Studi Sistem Informasi Universitas Telkom," vol. 4, no. 2, pp. 3114-3121, 2017.

[9] M. Nuris, "White box testing pada sistem penilaian pembelajaran," Skripsi Tek. Inform., pp. 1-102, 2015.

[10] D. W. Utomo, D. Kurniawan, and Y. P. Astuti, "Teknik Pengujian Perangkat Lunak Dalam Evaluasi Sistem Layanan Mandiri Pemantauan Haji Pada Kementerian Agama Provinsi Jawa Tengah," Simetris J. Tek. Mesin, Elektro dan Ilmu Komput., vol. 9, no. 2, pp. 731-746, 2018, doi: 10.24176/simet.v9i2.2289.

[11] V. V. Wang, A. S. Sukamto, and E. E. Pratama, "Sistem Pendukung Keputusan Seleksi Mahasiswa Penerima Beasiswa BBP-PPA dengan Metode
TOPSIS pada Fakultas Teknik UNTAN," J. Sist. dan Teknol. Inf., vol. 7, no. 2, p. 105, 2019, doi: 10.26418/justin.v7i2.29656.

[12] W. Fauzan, "Pembangunan aplikasi game puzzle And The Solver," Skripsi Tek. Inform., pp. 1-96, 2013.

[13] R. Budi, Belajar Otodidak Membuat Database Menggunakan MySQL. Bandung: Informatika, 2006.

[14] H. Heri, Cara Instan Menguasai Pemrograman Website Secara Otodidak. Jakarta Barat: Agogos Publishing, 2011.

[15] Pressman, Software Engineering A practitioners's Approach Sixth Edition. Singapore: McGraw-Hill International Edition, 2004. 